\title{
Pattern of nectar secretion in wild cherry, Prunus puddum Roxb, and the associated foraging behaviour of Apis cerana indica $\mathrm{F}$ and Apis mellifera $\mathrm{L}$
}

\author{
JK Gupta *, MCM Reddy, J Kumar \\ Department of Entomology and Apiculture, University of Horticulture and Forestry, \\ Nauni 173230 , Solan, India
}

(Received 1 July 1988; accepted 26 June 1989)

\begin{abstract}
Summary - Nectar sugar production per flower of Prunus puddum (during $8 \mathrm{~h}$ of flower opening) was $4.15 \mathrm{mg}$, when the nectar was removed at short intervals, compared to $1.89 \mathrm{mg} /$ flower in flowers of the same age where nectar was allowed to accumulate. Similarly, nectar removal every $24 \mathrm{~h}$ after flower opening resulted in more nectar sugar production. Flowers where nectar was allowed to accumulate resorbed nectar. Analysis of nectar revealed the presence of glucose, fructose, sucrose and 1 unidentified sugar. Honeybees (Apis cerana indica and $A$ mellifera) foraged both for nectar and pollen on the flowers. The activity of pollen gatherers peaked during early morning hours ( $8-9 \mathrm{~h}$ ) and that of nectar gatherers at $11 \mathrm{~h}$. A mellifera spent more time per flower than Ac indica, whether foraging for nectar or pollen. Honeybees preferred 24- and 48-h old flowers to freshly opened flowers or those older than $48 \mathrm{~h}$.
\end{abstract}

\section{Apis mellifera / Apis cerana indica / foraging behaviour / Prunus puddum / nectar secretion}

\section{INTRODUCTION}

Numerous wild plants are among the many valuable natural resources of the Himalayas and their presence is of utmost importance for beekeeping in Himachal Pradesh, India. Wild cherry, Prunus puddum Roxb (Family: Rosaceae), which flowers during the autumn, provides a good food bas for honeybees in the hills (1000-3000 $\mathrm{m}$ above sea level). In certain areas plantations are large and bees gather surplus honey from this source at a time when their other nectar resources are restricted.

The present paper reports the pattern of nectar secretion in $P$ puddum and associated foraging behaviour of Apis cerana indica $\mathrm{F}$ and $A$ mellifera $\mathrm{L}$. Observations are also made on the effect of nectar removal on nectar secretion in this plant. Some workers have reported an increase in nectar production if nectar is periodically removed from a flower (Maksymink, 1958; Kurennoi et al, 1967), whereas Pleasants (1983) found that total nectar production was the same whether nectar was removed or not.

\section{MATERIALS AND METHODS}

The present studies were carried out during November-December 1984, at Solan (Himachal Pradesh), India, situated at $1300 \mathrm{~m}$ altitude. Nectar production in the flowers at different time periods was measured by caging the floral buds

\footnotetext{
* Correspondence and reprints.
} 
(nylon net, 16 mesh size; $25 \times 15 \mathrm{~cm}$ ) and the flowers were marked on their opening (the flowers which had opened by $0900 \mathrm{~h}$ ). To measure the amount of sugar in flowers, the flowers were plucked and rinsed in $5 \mathrm{ml}$ of distilled water which was then analysed for total sugar as per the method of Roberts (1979). Ten replicates (each consisting of 1 flower) were maintained for each sampling hour. To determine the effect of nectar removal on nectar secretion, in 1 experiment nectar was removed from the flowers using 4-5 filter paper strips $(4.7 \times 0.4 \mathrm{~cm})$ at $2-\mathrm{h}$ intervals during a 1-day period (900 to $1700 \mathrm{~h}$ ) of flower opening. In a second experiment, nectar was removed at 24-h intervals after flower opening until the flowers started withering (ie up to $96 \mathrm{~h}$ of flower opening). The filter paper strips which were used to remove the nectar were rinsed in water, and dry sugar in the resulting solution was determined. Following the nectar removal experiments, the flowers were plucked and washed to determine the residual amount of sugar. Dry nectar sugar content in the flowers from which nectar was removed was compared with that of the flowers in which the nectar was allowed to accumulate.

Foraging activity of honeybees $A C$ indica and $A$ mellifera collecting nectar and pollen was recorded at hourly intervals, from 0700 to 1700 $h$ during the day (per $\mathrm{m}^{2}$ blooming branch/15 $\mathrm{min})$. Foraging rates of pollen and nectar gatherers of the 2 honeybee species were recorded (from $0830-1700 \mathrm{~h}$ ) for individuals by noting the time between alighting on a flower and departure. Ten foragers of each bee species were thus observed whether they collected nectar (the bees which extended their proboscis for nectar) or pollen (bees working on anthers). All the observations on foraging behaviour were continued for 3 sunny days and their means represented the foraging activity and foraging rate during a particular hour.

Observations were also recorded on the preference of honeybees to flowers of different ages (freshly opened, 24, 48, 72 and 96-h old flowers). Flowers of different ages were differentiated on the basis of colour changes in petals and stamen filaments, which were as follows: i), Freshly opened flowers - white petals, greenish white stamens; ii), $24 \mathrm{~h}$ - white petals, base of the stamen filament pinkish; iii), $48 \mathrm{~h}$ - light pinkish petals, medium pink coloured stamens; iv), $72 \mathrm{~h}$ - bright pink petals with pink stamens; v), $96 \mathrm{~h}$ - petals shrivelled.

The number of bees (of both species) visiting flowers of different ages was counted in a defined area. These counts were continued for 10 min at the beginning of each hourly count.

All the data were statistically analyzed using factorial randomized design and Student's $t$-test.

\section{RESULTS AND DISCUSSION}

In the flowers where nectar was removed at short intervals during the day, the maximum amount of sugar was present in flowers at $0900 \mathrm{~h}(2.97 \mathrm{mg} / \mathrm{flower})$ and thereafter amounts varied non-significantly between 0.18 to $0.40 \mathrm{mg} /$ flower $(1100-$ $1700 \mathrm{~h}$ ) (table I). This indicated that nectar

Table I. Daily production of nectar sugar by Prunus puddum flowers following periodic nectar removal. Nectar secreted during $8 \mathrm{~h}$ if : i) Nectar removed periodically : $4.15 \mathrm{a}^{*}$; ii) Nectar allowed to accumulate : 1.89b. *Values significantly different in Student's $t$-test $(P=0.05)$.

$\begin{array}{ll}0900 & 2.97 \\ 1100 & 0.18 \\ 1300 & 0.40 \\ 1500 & 0.28 \\ 1700 & 0.21 \\ \text { left out nectar } & 0.11 \\ (0.05) & 0.271\end{array}$


was never replenished completely after its initial removal at $0900 \mathrm{~h}$. This pattern of secretion contrasts to that observed in rape by Meyerhoff (1954) where nectar was replenished within 30 min of being removed. The total amount of dry sugar produced by a flower (from which nectar was removed) of $P$ puddum during the $8 \mathrm{~h}$ of the experiment was $4.15 \mathrm{mg}$ as compared to 1.89 in flowers of the same age where nectar was allowed to accumulate, thus revealing $\approx 120 \%$ more nectar secretion in the former as compared with the latter. The response of flowers to nectar extraction varies among different species. In apple flowers, nectar removal 5 times a day stimulated nectar production by 12.4$29.3 \%$ (Kurennoi et al, 1967), whereas in winter rape, nectar secretion increased by $\approx 128 \%$ if the nectar was removed 3 times a day (Maksymink, 1958). However, Pleasants (1983) did not find any increase in the total sugar production in lpomopsis aggregata (Polemoniaceae), even if nectar was removed periodically. It seems that influence of nectar removal on nectar production varies from plant to plant and that no generalization can be made. These studies are important since in most studies, 24-h sugar value is used to compare the nectar production in flowers and if repeated nectar removal increased the total nectar yield, as found in $P$ puddum, the 24$h$ value might be an underestimate in such cases, eg, the 24-h sugar value for $P$ puddum was $4.12 \mathrm{mg} /$ flower (fig 1), whereas an almost equal amount $(4.15 \mathrm{mg}$ ) of sugar was produced in $8 \mathrm{~h}$ if the nectar was repeatedly removed.

In the flowers where nectar was removed every $24 \mathrm{~h}$, the initial extraction of nectar from freshly opened flowers did not affect the total nectar production during the $24 \mathrm{~h}$ of flower opening (fig 1), but the second extraction (after $24 \mathrm{~h}$ ) resulted in a significant increase in the amount of sugar in the flowers visited by honeybees than in control flowers. The third extraction (from 48-h old flowers) did not affect the nectar production significantly. However, after the fourth extraction (from 72-h old flowers), nectar secretion was higher than in flowers in which nectar continued to accumulate. These control flowers showed a sudden drop of $3.34 \mathrm{mg}$ sugar/flower. Continued secretion is attributed to the stimulatory effect of nectar removal, whereas in the control flowers, the drop in total amount of sugar seems to be due to resorption of nectar by the nectaries. Such resorption has been reported by various workers in a variety of flowers (Lüttge and Schnepf, 1976; Corbet, 1978).

The quantitative analysis of the nectar of $P$ puddum revealed the presence of glucose, fructose, sucrose and 1 unidentified sugar in the ratio of $40.7: 39.5: 12.3$ : 7.48 , respectively. Thus the nectar was hexose-rich, and the fructose glucose ratio was 1.03. Fred (1976) found the fructose/ glucose ratio to be 1.0 or more in 26 Phillippine nectars. Battaglini and Battaglini (1974) also found nectars of different fruit

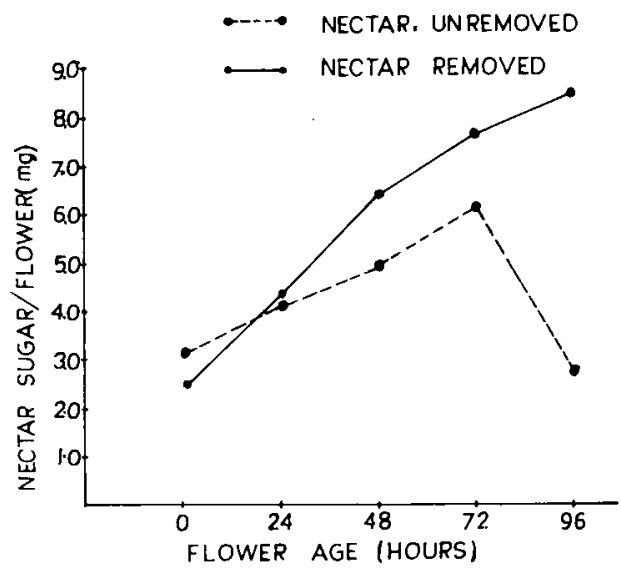

Fig 1. Effect of nectar removal on nectar sugar production in the flowers of $P$ puddum. 
trees to be rich in hexoses and poor in sucrose.

The honeybees, Apis mellifera and $A C$ indica were the principal foragers on the blooms, representing about $70 \%$ of the insect visitors. The honeybees gathered both nectar and pollen from the flowers throughout the day (fig 2), but the activity of pollen gatherers of both bee species was maximum during early morning hours $(0800$ and $0900 \mathrm{~h})$. This is probably related to peak of pollen presentation by the flowers. Percival (1955) found a peak of pollen presentation in cherry flowers during 0800-1200 $\mathrm{h}$. The proportion of pollen foragers in the 2 bee species did not vary significantly from one another during the course of a day. Similarily the nectargathering activity of both the bees was maximum at $1100 \mathrm{~h}$, and declined significantly during evening hours.
In general, pollen gatherers of either bee species spent less time/flower than nectar gatherers (table II). Time spent per flower by $A C$ indica nectar or pollen forager was less ( 3.25 and $7.32 \mathrm{~s}$, respectively) than by $A$ mellifera $(3.82$ and $10.38 \mathrm{~s}$, respectively). Time spent by nectar and pollen foragers of $A C$ indica and pollen foragers of $A$ mellifera was relatively constant throughout the day. However, nectar gatherers of $A$ mellifera spent significantly more time per flower at 1030 and $1230 \mathrm{~h}$ ( 11.30 and $11.10 \mathrm{~s}$, respectively) than at other times. Similar variation in time spent by $A$ mellifera per flower at different times was also reported by Gupta et al (1984) in flowers of Plectranthus rugosus. The rate at which bees visit fruit flowers depends on the amount of nectar, type of flower and climatic conditions as well as on the number of foraging insects (Free, 1970).

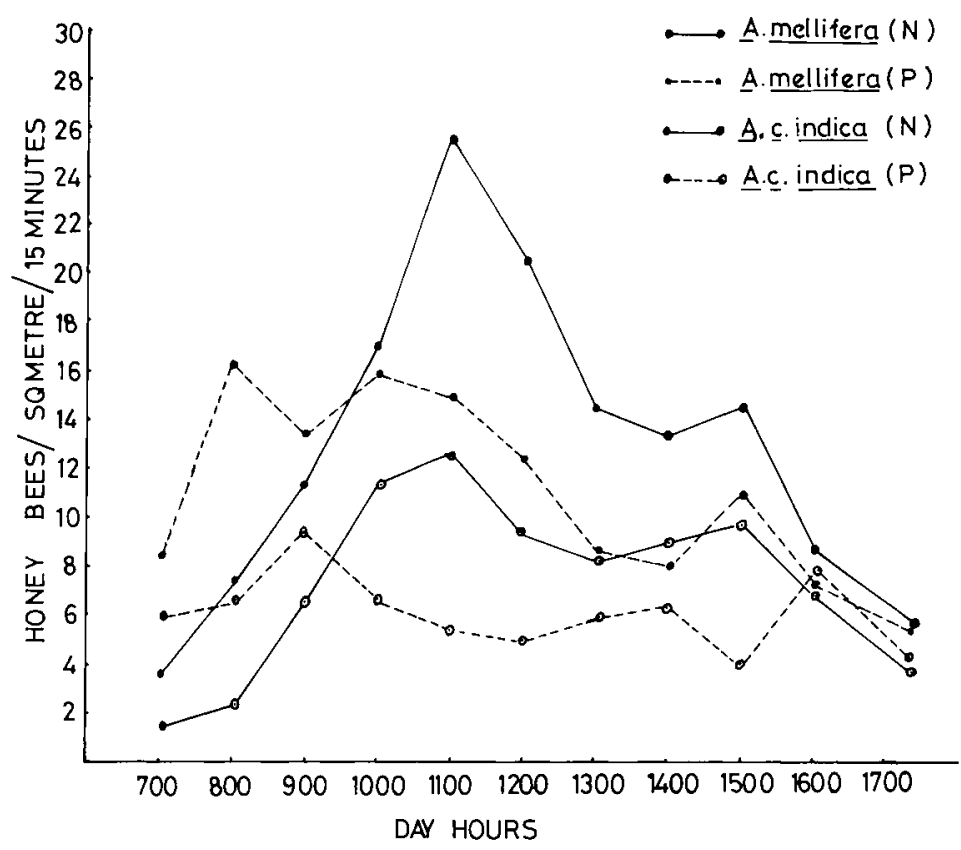

Fig 2. Foraging activity of nectar and pollen gatherers of $A c$ indica and $A$ mellifera on the flowers of $P$ puddum. 
Table II. Time (in s) spent per flower by pollen and nectar foraging honeybees on Prunus puddum flowers. $\mathrm{CD}(0.05)$; i) Pollen and nectar gatherers of the $A c$ indica and $A$ mellifera $=0.529$; ii) For any combination pair $=1.18$.

\begin{tabular}{ccccr}
\hline \multirow{2}{*}{$\begin{array}{c}\text { Time of } \\
\text { Observation }\end{array}$} & Pollen & Acindica & \multicolumn{2}{c}{ A mellifera } \\
& & & & Pollen \\
0830 & 3.40 & 7.14 & 3.70 & 9.70 \\
1030 & 3.74 & 7.40 & 4.44 & 11.30 \\
1230 & 3.00 & 7.60 & 4.10 & 11.10 \\
1430 & 2.74 & 7.20 & 3.40 & 9.70 \\
1630 & 3.40 & 7.30 & 3.50 & 10.10 \\
Mean & 3.25 & 7.32 & 3.82 & 10.38 \\
\hline
\end{tabular}

Honeybees preferred 24 and 48-h-old flowers as compared to freshly opened flowers and those older than $48 \mathrm{~h}$. This preference might be related to better nectar rewards (Reddy and Gupta, 1987).

Résumé - Sécrétion nectarifère du cerisier sauvage Prunus puddum Roxb et comportement de butinage d'Apis cerana indica $F$ et $\boldsymbol{A}$ mellifica $L$. Le travail a été réalisé à Nauni, Solan (Inde) à $1300 \mathrm{~m}$ d'altitude en novembre et décembre 1984 . Le but était de déterminer les modalités de la sécrétion nectarifère de Prunus puddum et le comportement de butinage des deux espèces d'abeilles.

Les résultats montrent qu'une fleur, qui reste éclose durant $8 \mathrm{~h}$, produit $4,15 \mathrm{mg}$ de sucre de nectar si celui-ci est prélevé à intervalles rapprochés et $1,89 \mathrm{mg}$ si on le laisse s'accumuler (tableau I). Le prélèvement du nectar toutes les $24 \mathrm{~h}$ entraine également une production de sucre par fleur plus élevée (fig 1). II y a résorption du nectar dans les fleurs lorsqu'on le laisse s'accumuler, ce que montre bien l'effondrement de la teneur en sucres des fleurs âgées de $96 \mathrm{~h}$. L'analyse du nectar a mon- tré la présence de glucose, de fructose, de saccharose et d'un sucre non identifié, dans les rapports respectifs de 40,7 : $39,5: 12,3: 7,48$. Le nectar est donc riche en hexoses.

Les 2 espèces d'abeilles (Apis cerana indica et $A$ mellifica) récoltent nectar et pollen sur les fleurs durant toute la journée (fig 2). L'activité des butineuses de pollen des 2 espèces est maximale entre 8 et $9 \mathrm{~h}$, tandis que le pic d'activité des butineuses de nectar se situe à $11 \mathrm{~h}$. Le temps que passe une butineuse de pollen par fleur est moindre que celui passé par une butineuse de nectar (tableau II). Les ouvrières d'A mellifica passent moins de temps par fleur que celles d'A $c$ cerana, que ce soit pour le pollen ou le nectar. Les abeilles préfèrent les fleurs de 24 et $48 \mathrm{~h}$ aux fleurs récemment écloses ou à celles qui ont plus de $48 \mathrm{~h}$.

Apis mellifica / Apis cerana indica / comportement de butinage / Prunus puddum / secrétion nectarifère

Zusammenfassung - Nektarsekretion bei der Wildkirsche, Prunus puddum 
Roxb, und das Trachtverhalten von Apis cerana indica $F$ und Apis mellifera L. Die vorliegende Untersuchung wurde in den Monaten November-Dezember 1984 in Nauni, Solan (Indien) in einer Seehöhe von $1300 \mathrm{~m}$ unternommen. Es sollten das Muster der Nektarabscheidung von Prunus puddum und das Trachtverhalten der beiden Bienenarten festgestellt werden.

Als Ergebnis zeigte sich, daß eine Blüte während $8 \mathrm{~h}$ ihrer Öffnungszeit $4.15 \mathrm{mg}$ Nektarzucker produzierte, soferne der Nektar in kurzen Intervallen entfernt wurde; dagegen waren es nur $1.89 \mathrm{mg}$, wenn sich der Nektar in der Blüte ansammelte (Tabelle I). Auch wenn der Nektar in Intervallen von $24 \mathrm{~h}$ entnommen wurde, zeigte sich eine höhere Zuckerproduktion per Blüte (Abb 1). In Blüten, in denen sich der Nektar ansammeln konnte, kommt es zu einer Nektarresorption, was sich aus dem Abfall des Zuckergehaltes in $96 \mathrm{~h}$ alten Blüten ergibt. Die qualitative Analyse des Nektars zeigte das Vorkommen von Glukose, Fruktose, Saccharose und einem unbestimmten Zucker im Verhältnis von $40,7: 39,5: 12,3: 7,48$. Der Nektar ist demnach reich an Hexosen.

Beide Bienenarten, Apis cerana indica und Apis mellifera, sammelten den ganzen Tag über sowohl Nektar wie Pollen (Abb 2). Die Aktivität der Pollensammler erreichte bei beiden Arten zwischen 8.00-9.00 $h$ ihren Höhepunkt, bei den Nektarsammlern um $11.00 \mathrm{~h}$. Die Zeit, die eine Pollensammlerin an einer Blüte verbrachte, war kürzer wie die einer Nektarsammlerin (Tabelle II). Sowohl beim Pollen- wie beim Nektarsammeln verbrachten mellifera- Bienen mehr Zeit in der Blüte als cerana-Bienen. Die Bienen bevorzugten 24 und $48 \mathrm{~h}$ alte Blüten im Vergleich mit frisch geöffneten und solchen, die über $48 \mathrm{~h}$ alt waren.
Apis mellifera / Apis cerana indica / Trachtverhalten / Prunus puddum / Nektarsekretion

\section{REFERENCES}

Battaglini M, Battaglini N (1974) Characteristics of the sugar fraction of the nectar from five tree species. Ann Tocalta 29, 441-455

Corbet SA (1978) Bee visits and the nectar of Echium vulgare $\mathrm{L}$ and Sinapis alba $\mathrm{L}$. Ecol Entomo/ 3, 25-37

Fred AR (1976) Sugars of some common Phillippine nectar. J Apic Res 15, 19-22

Free JB (1970) Insect Pollination of Crops. Academic Press, London

Gupta JK, Mishra RC, Kumar J (1984) Plectranthus as a forage for Apis $c$ indica and $A$ mellifera. Apidologie 115, 75-82

Kurennoi NM, Pravidine NN, Nikitenko MI (1967) Nectar production in apple flowers. $\mathrm{Tr}$ Slav Sel Khoz Inst 22, 106-109

Lüttge U, Schnepf E (1976) Transport in plants. II. B Tissues and organs. In: Encyclopedia of Plant Physiology. Vol 2, New Series (Lüttge U, Pitman MG, eds), Springer-Verlag, New York

Maksymink I (1958) Nectar secretion in winter rape. Przegl Zesz Nauk 2, 49-54 (in Polish)

Meyerhoff $G$ (1954) Untersuchungen über die Wirkung des Bienenbefluges auf den Raps. Arch Geflügelz Kleintierk 3, 259-306

Percival MS (1955) The presentation of pollen in certain angio-sperms and its collection by $A$ mellifera. New Phytol 54, 353-368

Pleasants JM (1983) Nectar production in 100 mopsis aggregata (Polemoniaceae). Am J Bot 70, 1468-1475

Reddy MCM, Gupta JK (1987) Wild cherry, Prunus puddum Roxb - A honey plant. In: Social Forestry for Rural Development (Khosla PK, Kohli RK, eds), ISTS, Solan

Roberts RB (1979) Spectrophotometric analysis of sugar produced by plants and harvested by insects. J Apic Res 18, 191-195 